\title{
The Role Of Professionalism Lecturer Of Mathematics On Research And Learning Processes In Campus
}

\author{
Murni $^{1}$ and Asmawati ${ }^{2}$ \\ \{murni_fkip@abulyatama.ac.id ${ }^{1}$, Asmawati@abulyatama.ac.id² \\ ${ }^{1,2}$ Lecturer at the University of Abulyatama
}

\begin{abstract}
Lecturer professionalism play a major role in improving the quality of the Research process . Lecturer whose main task in the field of research is required to have four competencies, namely competence in the field of study, competency in understanding of students, mastery of learning competency, and competence in personality and professional development. One of the mastery competencies of educating learning that needs to be possessed by lecturers in the context of creating conducive conditions for the student learning process is the competence of mastering the Research methodology.
\end{abstract}

Keywords: professionalism, learning process, research methodology

\section{Introduction}

Higher Education (college) as an institution providing higher education has a very large role in the framework of national development. There are two main tasks carried out by college, namely first, educating the nation's sons and daughters to master science and technology, and second, localizing national and regional development, including preparing candidates for high moral and democratic culture leaders [1]. Thus, indeed, college serves as the main producer of human resources for the needs of society, and to improve, disseminate, and develop science and technology itself ( Abdi A. Wahab, 2013 ). In carrying out its role, college faces major challenges in this era of globalization. Globalization characterized by a flood of information flows and the loss of boundaries between countries as a result of the development and advancement of communication and information technology must be responded to accurately and wisely. Thus, the existence of college in the community can still be maintained. Facing the challenges of globalization, the government has launched a new paradigm of higher education as stipulated in the Long-Term Higher Education Development Framework 1996 - 2005. This new paradigm centralizes the quality of higher education. The implementation continues to be strengthened by the government, in this case the Ministry of National Education, through the actualization of the principle of university autonomy (Depdiknas, 2013 ). In this article, the discussion is limited to the problem of the role of lecturer professionalism towards the research and learning process . Related to this problem, this article aims to describe the role of lecturer professionalism in relation to the research process . This exposure is expected to increase the lecturers ' insight and policy makers in universities in an effort to improve the professionalism of lecturers in order to improve the quality of the learning process to produce quality graduates as well. 


\section{Methodology Research}

The Tridharma College of higher education in Indonesia basically includes three important processes, knowledge creation, dissemination of knowledge (knowledge dissemination), and application or application of knowledge. Higher education as an enterprise knowledge should be placed research in a very important position. Research methods can be limited as practices and procedures used by teachers in the teaching and learning process [2]. A method is based on basic assumption about the nature of being taught and the nature of learning. In other words, a method has a foundation that is commonly called an approach . It is important to realize that each method has both strength and weakness. There is no super method that can be used in various situations and conditions of the teaching and learning process. Therefore, the use of methods must be selective. The mistake of choosing a method will have fatal consequences for the continuity of the teaching and learning process. Therefore, the selection of methods needs to be carefully considered. The things that are considered in the selection of methods are the objectives, characteristics of students, teaching abilities, the nature of learning materials, classroom situations, completeness of facilities, advantages and disadvantages of the method [3]. In essence, the choice of the method should be based on the effort to make the teaching-learning process take place effectively and efficiently. The method chosen must be believed to create conditions conducive to the learning process of students.

\section{Result and Discussion}

\subsection{Lecturer Professionalism}

Talks about the quality of college cannot be separated from the talk of lecturer professionalism. Lecturer as one of the components of college plays a very large role in realizing the quality of college. Lecturer with the main authority of teaching to deal directly with students in the teaching and learning process. In this arena the lecturers interact with students. In this educational interaction, it is expected that students experience the learning process and obtain learning outcomes as expected.

Many indicated that in general, lecturers do not have professional skills. Professional quality of lecturers still low [4]. [5] observation shows that in his class, lecturers is the main actor so that students are predominantly passive.

Research activities are one of the obligations of lecturers in implementing the Tri Dharma of higher education. Through research, many results and impacts can be used to develop science, technology and art, including developing the world of education. Another obligation of a lecturer is to carry out teaching in the classroom to convey learning materials and increase students' knowledge of scientific development. Ideally, the subject matter presented is up to date material derived from the results of recent research. Unfortunately, not a few lecturers who spend most of their time giving teaching and lack of time to do research. Through this program, lecturers are conditioned to conduct intensive and focused research with sufficient time. Thus, teaching activities and other additional tasks must be minimized to produce a research product that can be applied in real life.

What is the lecturer figure who is professional? To answer this question it is better to listen to the College of professionalism put forward by Hall in [6]. According to Hall, professionalism consists of five Colleges, namely community affiliation, the need to be independent, confidence in the rules themselves / profession, dedication to the profession, and social obligations. Community affiliation requires a professional to use professional ties as a 
reference, including formal organizations and informal colleague groups as the main source of work ideas. The need to be independent requires a professional to be able to make decisions independently. This professionalism is an element of motivation that contributes to high task performance [6]. The existence of this contribute relationship implies the need to increase professionalism for those who work in a profession, including the teaching profession .

Lecturer the professional is expected to have high performance that can satisfy all interested parties ( stakeholders ), namely students, parents, and society in the broadest sense. Besides satisfying stakeholders, this high performance also satisfies itself. For a professional, spiritual satisfaction is the main compensation expected from work. Meanwhile, material satisfaction is secondary.

\subsection{Lecturer Competence}

In the framework of organizing the Tridharma college, lecturer carry out three types of activities, namely education and research, research, and community service. As mentioned earlier, the main areas of lecturer activities is carrying out education and research. However, research activities and community service must also be carried out by a lecturer. Both of these activities will greatly support better education and research activities [7].

As a professional, lecturer required to have a number of competencies in order to carry out their duties properly. The competencies discussed below are only related to the main task of the lecturer, namely organizing education and research. So, the competency in question is lecturer competence as a teacher.

Competencies in the field of study cover two things, namely mastery of disciplines and curricular mastery. Mastery of scientific disciplines related to scientific substance and methodology. Curricular mastery relates to the selection, arrangement, packaging, and representation of material that is appropriate to the needs of students.

Mastery of educating learning is needed so that teachers can manage learning that is educational and student oriented. This competence is reflected, both in planning, implementing and evaluating. In designing learning, there are at least four things that need to be considered, namely goals (goals), students, teaching-learning methods and activities, and evaluation [8]. Learning that educates not only deals with transferring knowledge into students' brains, but also deals with attitude and mental development in order to make students as human beings who are more mature and more humane. In educating learning, the four pillars of education proclaimed by UNESCO should be reflected. The four pillars of education are learning to know, learning to do, learning to be, and learning to live together [9]. The first pillar relates to how students understand and appreciate the knowledge gained through interaction with their environment. The second pillar concerns the empowerment of students to be able to do (do something) to enrich their learning experience. So, here applies the principle of learning by doing. The third pillar relates to the process of forming independent, self-confident and confident people. The fourth pillar deals with the formation of personalities who understand pluralism and a positive and tolerant attitude towards diversity and differences in life. Thus, there will be a harmonious and peaceful atmosphere of life.

Personality and professional development competencies reflect the professional ability of lecturers to be able to know, measure, and expand its capabilities independently. In this case, lecturer always demanded to follow scientific developments, both with regard to the field of study ( subject matter) and with regard to pedagogical ( pedagogical content knowledge) . Both fields of science are needed by lecturers who have the main task of teaching [10]. A lecturer must initiate and be responsible for exploring various ways of obtaining information to develop capabilities independently. For this purpose, it can be done, for example, through cooperation with colleagues and the community. As a professional personality, a lecturer in carrying out their duties always oriented to the benefit of students. So, the orientation is to 
meet the needs of responsible and humane students. By paying attention to the picture, it appears that the learning process is a factor that is directly related to learning outcomes. While the learning process itself is influenced directly by the teacher and students. Teachers are influenced directly by three factors, namely material and material presentation systems, administrative systems, and evaluation systems. The administration system itself is influenced by the curriculum system. Student factors are influenced by five factors, namely cognitive background, affective background, socio-economic background, material and material presentation system, and environment. This learning process directly affects learning outcomes, which can include cognitive, affective, and ability aspects. The ability meant here is psychomotor ability. The picture above also shows that the learning process can be seen from the high level of student participation in participating in teaching and learning activities, and from the role of the teacher to create a conducive atmosphere for the learning process. Student involvement in the teaching and learning process is not limited to mental involvement, but also physical and emotional involvement.

\subsection{Lecturer Research}

There are 3 main duties of a lecturer, namely teaching, research and community service. These tasks are neatly packaged in the Tridharma Perguruan Tinggi that has been held. That means the task of a lecturer besides teaching also guides students. Lecturers are also required to conduct research, and dedication to the surrounding community. Unfortunately, these last two points are still often considered a 'side job'. A lecturer focuses more on his routine assignments as a teacher and student guide rather than doing new innovations through research activities. Mhrough a study can be found understanding, technology and new solutions to diverse problems faced by various parties, both students, the college itself and the broader community. That means he is required to be able to criticize existing knowledge. Not only as recipients of passive information, but active learners. For this reason, support for relevant research results is needed to support existing lecture material. Through the support of relevant research results and up to date. Even insight common sense a student will also be honed. This certainly can support a student to have the ability to be an innovative and creative figure in answering every future development challenge.

\section{Conclusion}

In this era of globalization, college faces great challenges. for this reason, it is necessary to improve the quality of the learning process in order to produce qualified graduates. To improve the quality of the learning process in college, it is demanded to increase the professionalism of lecturers . Professionalism implies four competencies that lecturers must possess, especially the competence of lecturers related to the main tasks as instructor and educator, namely the competence of the field of study, the understanding of students' competencies, the learning competencies that educate, and the development of personality and professional competence. The method is an important aspect in creating conditions conducive to the learning process of students. Therefore, the lecturer the professional must have methodological competence which is one of the educational learning competencies. Based on the above conclusions, it is recommended that universities always improve the professionalism of lecturers which includes the four competencies above. In addition, the competency of the lecturer methodology also needs to be improved to support one of the educational learning competencies. 


\section{References}

[1] S. Effendi, University Management Facing Global Challenges. Makasar: Presented at the National Seminar of the Indonesian Chancellor Assembly, 2013.

[2] D. Nunan, Language Teaching Methodology, A text book for teacher. New York: Prentice Hall, 2016.

[3] Sugiyono, S.B, Teachers and Students in Education Interaction. Jakarta: Rineka College, 2013.

[4] A. Mahmud, "Lecturer Performance and Motivation Judging from the Style of COLLEGES Leaders in NTB Province," Educ. J. Sci. Commun. Media, vol. No 2, no. 1, 2015.

[5] C. R. Semiawan, Higher Education Enhances Human Ability as OCollegeimum as possible. Jakarta: Ministry of Education and Culture, 2015.

[6] Guntur, Y.S, B. Soepomo, and Gitoyo, "Analysis of Experience Effect on Professionalism and Analysis of the Effect of Professionalism on Outcomes," vol. 1, 2015.

[7] Directorate of Research and Community Service, "Research and Community Service Policies and Programs," 2015.

[8] J. Kemp, Research Design Process (translation). Bandung: ITB, 2014.

[9] D. Budimansyah, Portfolio Based Learning and Assessment Models. Bandung: Genesindo, 2015.

[10] P. Grossman, Mapping the terrain: Knowledge Growth in Teaching . In Waxman, HC and Walberg, HJ (Ed.), Effective Teaching: Current Research. Berkeley: McCutchan, 2016. 